\title{
Chromosome 6a
}

\section{Figure A}

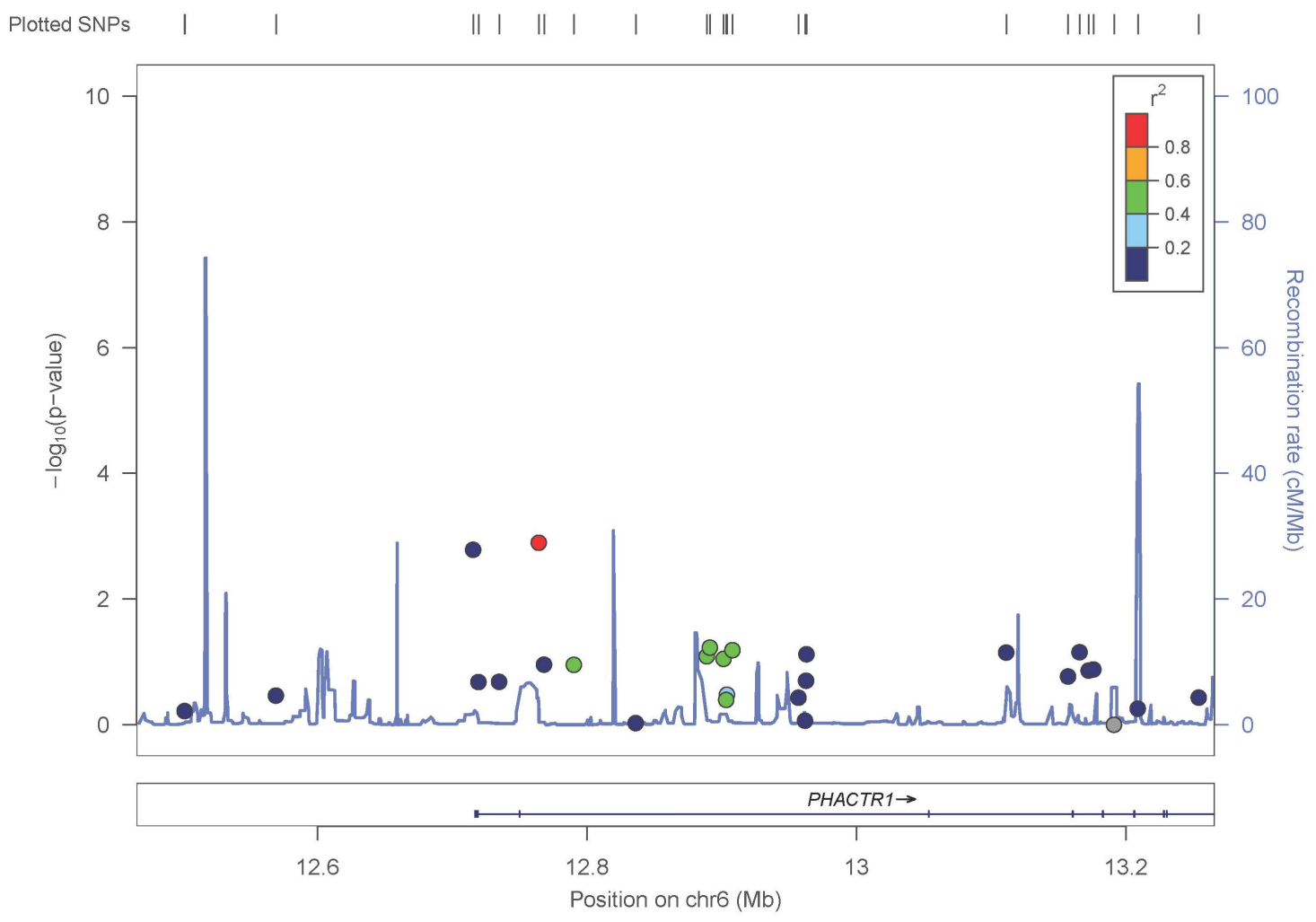

Chromosome 6a

Figure B

Chr 6a

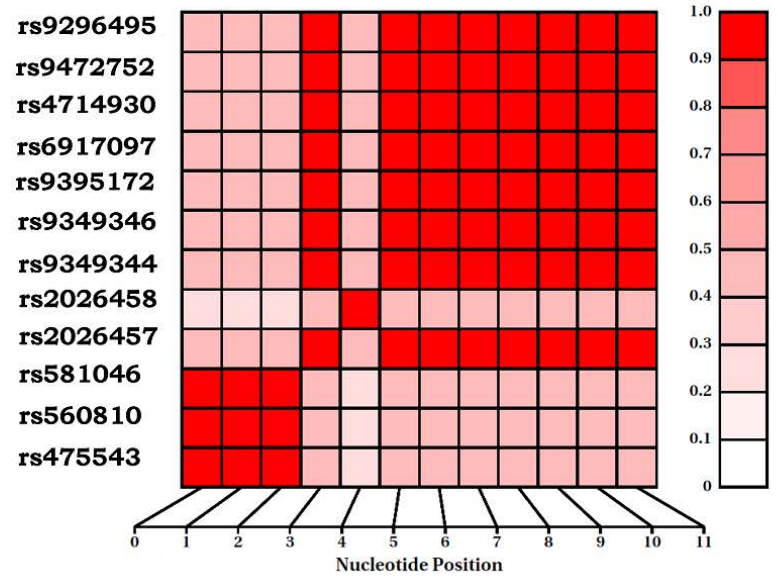

